\title{
Clinical Significance of Hepatitis B Surface Antigen in Cord Blood of Hepatitis B e-Antigen-Negative Chronic Hepatitis B Virus-Infected Mothers
}

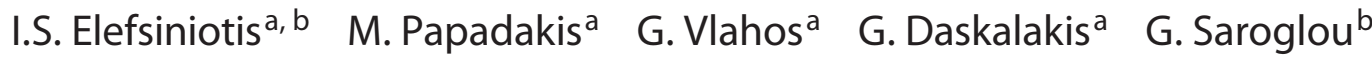 \\ A. Antsaklis ${ }^{a}$ \\ a First Department of Obstetrics and Gynecology, University of Athens, 'Alexandra' Hospital, and \\ ${ }^{b}$ Department of Internal Medicine-Hepatology and Infectious Diseases Unit, 'Elena Venizelou' Hospital, \\ University of Athens, Athens, Greece
}

\section{Key Words}

Hepatitis B surface antigen · Cord blood · Hepatitis B virus • Vertical transmission

\begin{abstract}
Vertical transmission of hepatitis B virus (HBV) infection during the perinatal period is the major cause of HBV transmission. The aim of our study was to evaluate the serological and virological profiles of HBV infection in cord blood samples obtained from HBeAg-negative chronic HBV-infected women, at delivery, and to investigate their relationship with the clinical outcome (possible transmission of HBV) in neonates receiving the currently approved passive-active immunoprophylaxis schedule. Sixteen women (32\%) exhibited $\mathrm{HBsAg}$ positivity in the cord blood but HBV-DNA has not been detected in any of the 50 cord blood samples evaluated. We conclude that $\mathrm{HBsAg}$ can be transferred through the placental barrier, as with other proteins, in about one third of HBeAg-negative chronic HBV-infected pregnant women, irrespective of the maternal viral load, the mode of delivery or the placenta HBV pathology. The clinical impact of this phenomenon on the intrauterine-transplacental or perinatal transmission of HBV infection and/or passive-active immunoprophylaxis failure does not seem to be important.

Copyright $\odot 2009$ S. Karger AG, Basel
\end{abstract}

Vertical transmission of hepatitis B virus (HBV) infection during the perinatal period is the major cause of HBV transmission in endemic countries [1]. In countries with high HBV prevalence, intrauterine/transplacental transmission is observed in a significant proportion of pregnancies, resulting in passive-active immunoprophylaxis failure and dissemination of the HBV infection $[2,3]$.

In Greece, the overall seroprevalence of HBsAg positivity among women of reproductive age is relatively low, but is higher among immigrants who live and work in our country [4]. The vast majority of HBsAg-positive women in our country (>95\%) are HBeAg negative [5]. Despite that, about a third of them exhibit high or even extremely high viral load during the perinatal period [5], mainly due to a precore mutation (G1896A) of the HBV genome. Data concerning the serological and virological profiles of cord blood, as well as of the placental pathology for $\mathrm{HBV}$ antigens, from HBeAg-negative chronic HBV-infected women in Europe are limited.

The aim of our study was to evaluate the serological and virological profiles of HBV infection in cord blood samples obtained from HBeAg-negative chronic HBV-infected women at delivery, and to investigate their relationship with the clinical outcome (possible transmission of $\mathrm{HBV}$ ) in neonates receiving the currently approved passive-active immunoprophylaxis schedule.

\section{KARGER}

Fax +4161306 1234 E-Mail karger@karger.ch www.karger.com (c) 2009 S. Karger AG, Basel

0300-5526/09/0523-0132\$26.00/0

Accessible online at:

www.karger.com/int
Ioannis S. Elefsiniotis, MD

Carchidonos 9

GR-16562 A. Glyfada (Greece)

E-Mail ielefs@nurs.uoa.gr 

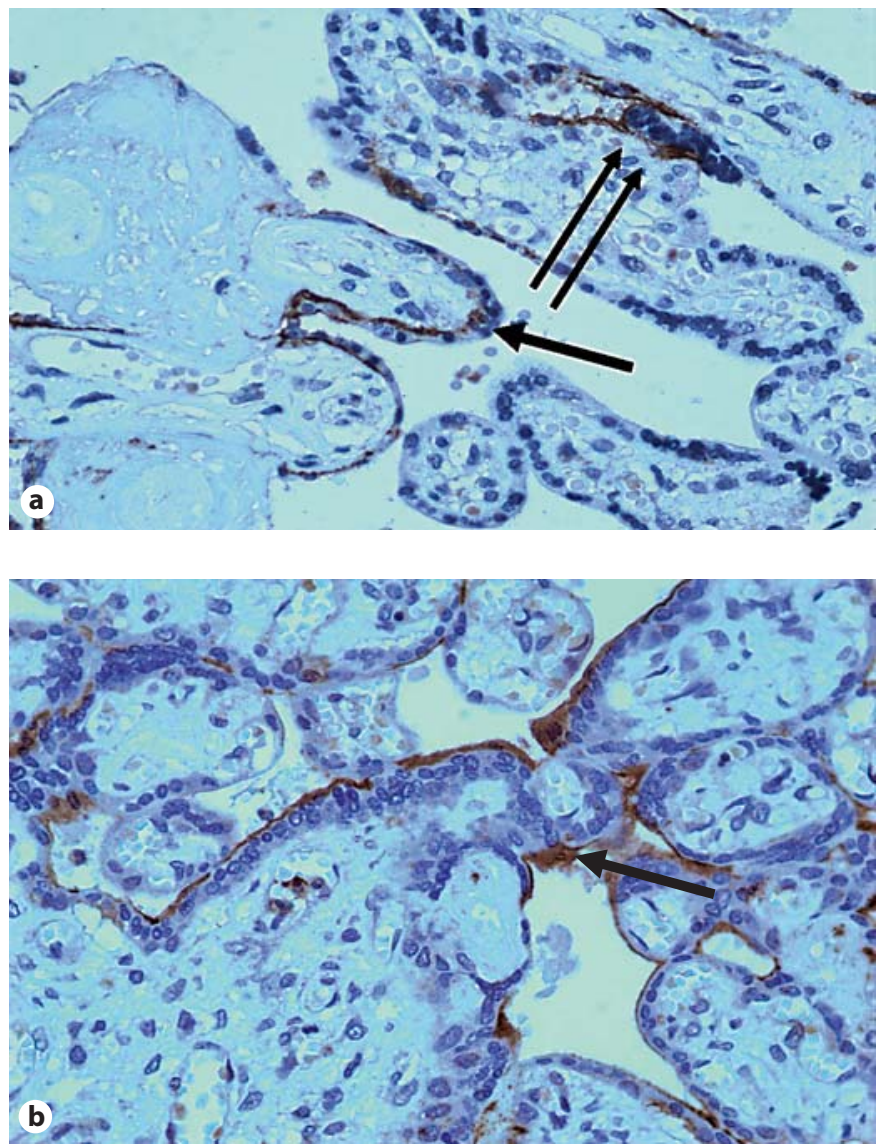

Fig. 1. $\mathrm{HBcAg}$-positive stained placental tissue (a, b, the arrows show brown-colored positive staining), HBsAg-negative stained placental tissue (c) and $\mathrm{HBcAg}$-negative stained placental tissue (d). In 3- $\mu \mathrm{m}$ formalin-fixed and paraffin-embedded sections, the presence of $\mathrm{HB}$ surface and $\mathrm{HB}$ core antigens were studied using the Envision HRP immunohistochemical method. The anti-HBs
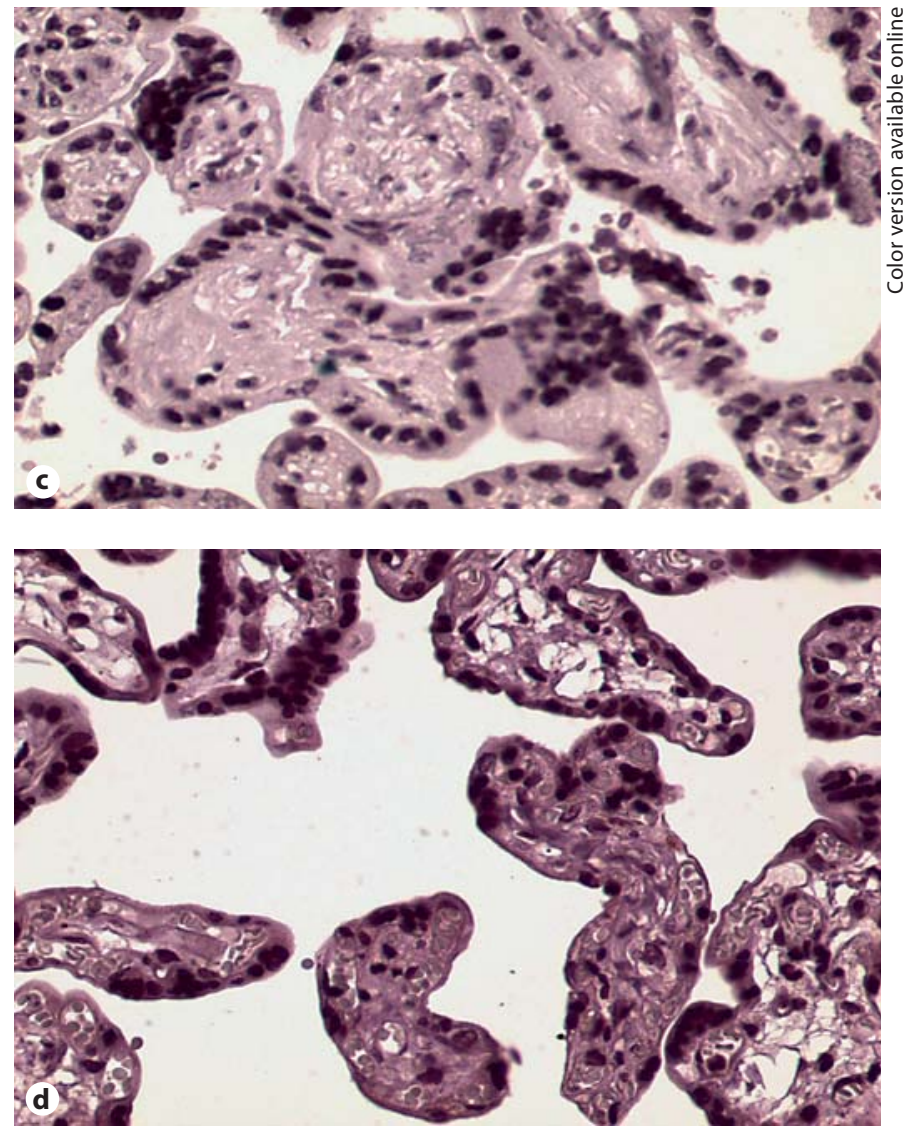

Ab was mouse anti-human monoclonal (clone 3E7) and was used at a dilution of 1:50. The anti-HB core antigen was rabbit-polyclonal and was used at a dilution of 1:500. A piece of liver biopsy tissue from a patient with chronic hepatitis B was used as control.

HDV were excluded from the study. Serological re-evaluation of the infants was performed at the age of 12 months. Transmission of HBV infection to neonates was confirmed by detectable HBV-DNA in their serum and/or serum HBsAg positivity at the age of 12 months.

During the study period, 72 chronically HBV-infected women had delivered at our department and 50 of them were eligible for the final analysis. Twenty-two (44\%) had caesarean sections and 28 (56\%) had natural deliveries. Twenty-two women (44\%) exhibited detectable serum HBV-DNA, while in 28 (56\%), serum HBV-DNA was undetectable ( $<400$ copies/ml, Amplicor/Roche) at the perinatal period. Four of 22 (18.2\%) HBV-DNA-positive women had high viral load, defined as HBV-DNA $>10,000$ copies $/ \mathrm{ml}$. 
Table 1. Virological and serological data obtained from serum and cord blood samples of pregnant women and data obtained from placenta staining for HBV antigens

$\begin{array}{lc}\text { Women's serum }(\mathrm{n}=50) & \\ \text { HBV-DNA positive } & 22 / 50(44) \\ \text { HBV-DNA negative } & 28 / 50(56) \\ \text { HBV-DNA >10,000 c/ml } & 4 / 22(18.2) \\ \text { Cord blood }(\mathrm{n}=50) & \\ \text { HBsAg positive } & 16 / 50(32) \\ \text { antiHBc positive } & 50 / 50(100) \\ \text { antiHBe positive } & 50 / 50(100) \\ \text { HBV-DNA positive } & 0 / 50 \\ \text { Placenta immunopathology }(\mathrm{n}=25) & \\ \text { HBsAg positive } & 0 / 25 \\ \text { HBcAg positive } & 8 / 25(32)\end{array}$

Numbers in parentheses denote percent values.
Twenty-five specimens of placental tissue were evaluated for the presence of $\mathrm{HBsAg}$ and/or HBcAg. In all of them, staining for HBsAg was negative, whereas 8 (32\%) were weakly positive for $\mathrm{HBcAg}$ (table 1, fig. 1), irrespective of the presence or absence of viremia or the maternal viral load.

The presence of HBsAg in the cord blood of chronic HBV-infected women was not linked to the mode of delivery in the whole group $(\mathrm{p}=0.559)$ or in the subgroups of viremic women with high or low serum HBV-DNA levels $(p=0.675)$. Moreover, the mode of delivery did not seem to have an impact on the placenta staining for HBV antigens.

All 50 neonates evaluated at days 1 and 3 after birth were HBV-DNA negative, and HBV transmission was not observed in any of them. It is important to note that $2 / 4$ (50\%) infants born from HBeAg-positive mothers (who were excluded from the final analysis) exhibited passiveactive immunoprophylaxis failure and finally acquired $\mathrm{HBV}$ infection (HBsAg and HBV-DNA positivity at the age of 12 months).

In conclusion, $\mathrm{HBs} A g$ can be transferred through the placental barrier, as with other proteins, in about one third of HBeAg-negative chronic $\mathrm{HBV}$-infected pregnant women, irrespective of the maternal viral load, the mode of delivery or the placenta HBV pathology. The clinical impact of this phenomenon on the intrauterine-transplacental or perinatal transmission of HBV infection and/or passive-active immunoprophylaxis failure does not seem to be important.

\section{References}

Soderstrom A, Norkrans G, Lindh M: Hepatitis B virus DNA during pregnancy and post partum: aspects on vertical transmission. Scand J Infect Dis 2003;35:814-819.

$\checkmark 2$ Zhang SL, Yue YF, Bai GQ, Shi L, Jiang H: Mechanism of intrauterine infection of hepatitis B virus. World J Gastroenterol 2004;10: 437-438.

- 3 Xu DZ, Yan YP, Choi BC, Xu JQ, Men K, Zhang JX, Liu ZH, Wang FS: Risk factor and mechanism of transplacental transmission of hepatitis B virus: a case-control study. J Med Virol 2002;67:20-26.
-4 Elefsiniotis IS, Glynou I, Pantazis KD, Fotos N, Magaziotou I, Kada H: Prevalence of chronic HBV infection among 13,581 women at reproductive age in Greece: a prospective single-center study. J Clin Virol 2005;32: 179-180.

5 Elefsiniotis IS, Glynou I, Magaziotou I, Pantazis KD, Fotos N, Brokalaki H, Kada H, Saroglou G: HBeAg negative serological status and low viral replication levels characterize chronic hepatitis B virus-infected women at reproductive age in Greece: a one-year, prospective single-center study. World J Gastroenterol 2005; 11:4879-4882. 